\title{
Leitura de Chartier ${ }^{1}$
}

\author{
Joāo Adolfo Hansen \\ Departamento de Letras Clássicas e Vernáculas da FFLCH-USP
}

\begin{abstract}
Lecr un soneto de Quevedo pensando que lo escribio con una plumo de gansa
\end{abstract}

CABRERa INFANTE

Falo aqui à moda do braconneur definido por de Certeau: como um caçador furtivo, que avança por territórios alheios, pilhando aqui e ali o que lhe interessa, segundo uma tática de apropriação que passa pelos trabalhos de Roger Chartier para neles capturar categorias analíticas de interesse heurîstico para aqueles que, como eu, trabalham com literatura na forma de uma atividade histórica.

Quero começar falando do título do seu último texto publicado no Brasil, A Ordem dos Livros, para tomá-lo como um índice geral da natureza da sua prática historiográfica. Sinteticamente, o título indica a grande complexidade das suas operaçōes. O duplo genitivo, subjetivo e objetivo, propōe que os textos são o objeto das apropriaçōes que os ordenam e distribucm por vários regimes de significaçāo e sentido, mas também indica que produzem novas ordens de apropriaçōes imprevistas, que de algum modo subvertem a ordenaçāo inicial com que foram modelados e as classificaçōes a que foram submetidos. Os livros são lidos, certamente, mas também lêem os leitores. Assim, se o título A Ordem dos Livros pode ser entendido referencialmente, como a ordenação diacrônica que, entre o século XIV e o XVIII, foi imposta à multiplicidade das práticas do signo, como uma espécie de domínio classificatório que Chartier reatualiza nas formas da leitura, da autoria e da biblioteca, também significa que o livro produz novas ordenaçōes sincrônicas e virtuais, impossíveis de serem totalizadas. Deste modo, A Ordem dos Livros se constrói programaticamente como a figura de um inacabamento perpétuo, pois o duplo trabalho está se refazendo sempre, como agora, na intersecção de estrutura e usos, de coerção e liberdade, de dependências e diferenças.

Como se sabe, Chartier propōe três articulaçōes integradas de análise como condiçōes de possibilidade de se determinar a estrutura das prescriçōes, a função das apropriaçōes e os valores dos usos dos objetos: a primeira é a da modelização retórica dos textos, como convenção técnica aplicada num ato

1. A propósito de conferência dada pelo Professor Roger Chartier em setembro de 1994 no Instituto de Estudos Avançados - IEA, sob título “Texto, Impressos e Leituras", publicado na Revista de História $\mathrm{n}^{\mathrm{a}} 132$. 
de discurso que, ao transformar a codificaçăo semiótica da língua, semantiza-se como enunciado em situaçāo nas várias acepçōes de opus, "obra" ou "texto". Aqui já se observa uma diferença em relação aos modelos de inteligibilidade literária do texto fornecidos pela lingüística estrutural. Sabe-se que, para que a lingüística fosse constituída como ciência rigorosa, seus inventores fizeram abstração dos usos, ou das falas, reduzindo o fonćtico ao fonológico, e as performances à gramaticalidade da frase e da sintaxe. A generalização da lingüística como modelo-piloto da teoria literária - por exemplo, nos formalistas russos e tchecos, no New Criticism e nas teorias gerais da narratividade que foram feitas nos anos 60 - fez com que os textos litcrários passassem a ser lidos segundo os modelos abstratos da língua - a fonologia, a frasc, a sintaxe - apagando-se quase sempre o fato de que os textos sāo discursos, enunciados ou produtos, como investimento de um corpo numa forma fonética, numa forma semântica e numa pragmática. Em Chartier, assistimos ao retorno do enunciado recalcado, o que se evidencia, por exemplo, na sua retomada da categoria autoria como elemento constitutivo do sentido. Evidentemente, não reduz a autoria ao produtor empírico, nem à concepção romântica da expressão psicológica "original", mas propõe a função-autor como um modo de classificação e distribuição dos discursos que implica determinadas escolhas de materiais e orientações de leitura assinaladas como um "ponto de vista" nos dispositivos textuais. Assim, demonstra que por vezes os textos sāo perspectivados numa iniciativa subjetivada, que se individualiza como autoria, por vezes num ato anônimo, que se coletiviza como auctoritas. Os objetos produzidos pressupöem, por isso, nos usos que fazem das prescrições retóricas do seu gênero, uma presença classificatória que os distribui segundo os regimes de legibilidade e intencionalidade de uma função autoral. Sua própria forma prescreve os mo- dos e os sentidos com que devem ser lidos - literatura, filosofia, ciência, religiāo, política, poesia como se a representação fosse ao mesmo tempo mimética e judicativa, como diz Weimann, ou representativa e avaliativa. Assim, se os objetos discursivos modalizam o sentido da sua representação segundo um "ponto de vista", ou seja, se eles fazem uma transformaçāo do material que se pode caracterizar como a deformaçāo de um valor de uso da matéria semiótica da língua e das convençōes retóricas de representaçāo, a determinação dessas convençōes e dos critérios dessas deformaçōes será bá. sica para se determinar a forma mentis que organiza o discurso como um padrão ou um modelo cultural.

A segunda articulação poderia ser resumida pelo poema de Cabrera Infante que propus como epígrafe de minha fala - "Ler um soneto de Quevedo/ pensando que o escreveu/ com uma pluma de ganso". Ou seja: a da materialidade dos suportes e meios de circulação dos discursos. Por exemplo, volumen que se desenrola, codex que se folheia, manuscrito redigido ou ilustrado como pluma ou ponta de metal, texto datilografado, computadorizado, ou impresso, cordel, livro, panfleto, volume isolado ou de coleção, capítulos, paginação, exórdios, prefácios, posfácios, notas - e toda a variedade grande dos materiais - papiro, pergaminho, papel, fitas, disquete - e dos tipos de letras, dimensões das páginas etc. Aqui, o interesse da operação de Chartier consiste principalmente no fato de incluir a matéria no sentido, evidenciando o suporte ou a ordenação material da mensagem e do signo. Logo, a significação do texto não pode ser dissociada da matéria que organiza a forma da sua percepção nas apropriaçōes.

A terceira articulação é a da materialidade do consumo produtivo, em que um ouvinte ou um leitor assumem a posiçāo de autoria quando, coincidindo ou nāo com a posição do destinatário formalizado no contrato enunciativo do discurso, torna-se um autor dotado também de competência ou autori- 
dade. $O$ consumo semantiza a representação em situaçōes múltiplas e segundo códigos e posicionamentos variados, que vão desde a tautologia pura c que, acontecendo depois, já é diferença, até a paródia mais radical e que, citando o que veio antes, é dependência, e outros usos e sentidos incontrolávcis. Charticr demonstra, no caso, que importa que se considerem os protocolos e as comunidades de leitura, as classificaçōes, os regimes de circulação, as exclusōes, as censuras, as censuras da atenção, os tempos, a oralização, a memorização, a leitura silenciosa etc.

Acredito, por isso, que a originalidade interessantíssima do seu trabalho é a de evidenciar-se como um ponto, por definição móvel, de intersecção ou de apropriação de vários saberes do signo, que inclui e soluciona aporias de estudos estruturalistas e marxistas de literatura. Em sua operação, parece-me central o conceito de Aneignung, apropriaçāo, como na definição de Marx do trabalho que, enquanto transforma materiais produzindo valores de uso de um objeto numa situação determinada e segundo uma posição determinada na produçāo, também produz um sujeito para o objeto. Chartier desloca-se, contudo, da determinação macroestrutural e univogi da infraestrutura pressuposta nos estudos de literatura que entendem a Aneignung de Marx como doutrina do reflexo e que costumam propor a determinação unívoca do simbólico pelo econômico e, por vezes, pelo político, fazendo do discurso uma representação segunda, como re-apresentação mais ou menos adequada de algo já dado, apresentado e conhecido como "o real". Por isso, sua operação também permite a crítica desse "conceito tênue de real", como dizia Foucault, que faz com que os discursos sejam entendidos como um espelho onde se deposita a imagem pálida de algo já conhecido na base e que se oferece ao re-conhecimento. Na operaçāo de Chartier, os discursos são reais e absolutamente contemporâneos de seu tempo, obviamente. Como os discursos são práticas, sua operação descarta também a concepção empirista que os pōe como um instrumento transparente para se atingir a consciência do sujeito das práticas como uma unidade prévia de consciência, alienada ou nāo, mas prévia à própria prática discursiva onde sua representaçāo aparcce como ideologia.

A noção de apropriaçāo de Chartier relacionase, assim, às condiçōes de possibilidade de uma iniciativa individual de uso dos objetos que pode, inclusive, subverter-lhes o sentido inicial. Por isso, também diverge de Foucault, que propõe apropriação como dispositivo disciplinar com que as instituiçōes gravam os signos da repressão nos corpos.

Com isso, principalmente no primciro capítulo de A Ordem dos Livros, que trata das comunidades de leitores, apropriação nāo se caracteriza pela transferência metafórica de uma categoria econômica, como "produção", para a leitura dos textos, como ocorre na "crítica escritural" dos anos 60 e 70, como a de Barthes e Kristeva. Quero dizer: a operação de Chartier nāo é uma nova textualização da subjetividade entendida como efeito determinado pela estrutura da língua ou do inconsciente, como ainda sugere o Foucault de L'ordre du discours. Também nāo é uma interpretação ou uma hermenêutica, como um comentário ou uma subjetivação da textualidade que, ao entender os objetos culturais como relaçāo intersubjetiva de consciências, abstrai seu meio material.

Com as três articulações, mediadas sempre pelo conceito de apropriaçāo, a operação de Chartier faz com que os objetos falem a partir da sua matéria, isto é, a partir de si mesmos, como escreve em $A O_{r}$ dem dos Livros. O procedimento impede que o sentido seja dissociado das condiçōes e dos meios materiais, impedindo também que a representação seja definida de modo unívoco, ora como um reflexo secundário, ora como restrição disciplinar, ora como expressāo psicológica ou diálogo espiritual de consciências. 
As catcgorias de prática e de representaçāo, operadas em conexão com a de apropriaçăo, têm grande valor heurístico para o estudioso de literatura interessado em desenvolver uma atividade histórica relacionada com o conceito de formalidade das prá. ticas de Norbert Elias e de Michel de Certeau, pois permitem desnaturalizar as representaçōes e deslocálas da generalidade trans-histórica de categorias mágicas, rotinciras nos estudos brasileiros, como as de "influência", "importação de idéias", "imitação" c outras. Elas têm especial interesse para os discursos anteriores ao romantismo que chegaram ao presente na forma dos resíduos do arquivo. Elas permitem que se dissolva a naturalidade da presença dos resíduos no cânone literírio, também permitindo criticar a naturalidade das suas interpretaçōes dominantes, por exemplo, quando se evidencia que sua inclusāo no cânone é o resultado de longos encadeamentos de apropriações polêmicas e contraditórias e que a interpretaçāo, como no dito de Marx, por considerar as formas anteriores como etapas para si mesma, costuma conceber as formas passadas de maneira unilateral. A dissoluçāo da naturalidade da representaçāo faz com que os resíduos falem a partir de si mesmos c, para isso, os reatualiza como evidências de práticas datadas, isto ć, como representaçōes de práticas que resultam de práticas de representaçāo.

Quando se determina o caráter dessas práticas, pode-se também especificar o caráter das representações que clas produzem e, uma vez que as mcsmas práticas são formalizadas culturalmente, também se evidencia que são representações.

Aqui, quero entrar no campo das práticas letradas luso-brasileiras dos séculos XVII e XVIII, relacionando as categorias de Chartier com os modelos culturais e a matcrialidade que especificam essas práticas. $O$ principal modelo cultural que define a excelência humana nas letras luso-brasileiras do XVII e ainda do XVIII é o tipo do discreto. Ele é considerado invariavelmente com as virtudes do cortesāo e do perfeito cavaleiro cristāo: distingue-se pelo engenho e pela prudência, que fazem dele um tipo agudo e racional, dotado de meios retóricos e éticos que o tornam senhor absoluto dos protocolos dos decoros $\mathrm{e}$, portanto, da recepção. Como no provérbio de Veneza, degli effeti nascono gli affeti, o discreto conhece os estilos adequados às ocasiōes da hierarquia. No caso, ć a agudeza conceituosa quc o distingue do tipo do vulgar, pois o engenho e o juízo são aptos para compreender a dificuldade programática dos discursos como distinçāo social. Quando Góngora, por exemplo, afirma que descja escrever grego e ser obscuríssimo, declarando escribo no para muchos, cvidencia a auctoritas de sua poesia como emulação do modelo do discreto. Retoricamente, a agudeza seiscentista é hermética porque é culta: aproxima conceitos distantes e os funde numa metáfora cuja interpretação depende do juízo e do engenho ausentes do vulgo, scgundo a convenção. Logo, quando a poesia seiscentista figura destinatários discretos, o hermetismo é a regra, segundo estilos próprios de discretos: mas quando o vulgo é tema ou receptor, impōc-se a clareza, por exemplo, a obscenidade, claríssima. Por outras palavras, nessas práticas a discrição também consiste no fingimento da falta de discriçāo, efetuada nos gêneros cômicos como o artifício de uma natureza néscia que diverte néscios com falas néscias, como ć o caso de Lope de Vega, imitado nas letras luso-brasileiras, quando afirma em seu Arte Nuevo de Hacer Comédias en Este Tiempo quc cscrevc segundo a arte inventada pelos que pretenderam o aplauso vulgar e que, por isso, é justo falar como néscio para agradar néscios.

Segundo uma leitura determinada da codificaçāo retórica dos tipos do discreto c do vulgar, em que a retórica é entendida como prática de aplicaçāo de esquemas de formas por aqueles que se apropriam do modelo do discreto e também como representação discreta, os resultados que venho obtendo com o es- 
tudo das principais preceptivas do XVII metaforizam - o que Chartier diz, com Elias, sobre a sociedade de Corte: nela, a identidade se define como representaçāo c pela representação: o poder é dedutível das aparências e a posição, da forma da representação. Assim, pode-se demonstrar que a discrição é o diferencial que especifica a afetação das apropriaçōes que aplicam as agudezas sem conhecimento dos decoros ou dos protocolos de seus usos. Logo, o modelo cultural do discreto forneçe os critérios cultos da legibilidade dessas práticas: ética aristotélica, prudência católica, dissimulaçāo honesta, juízo e agudeza. É a retórica aristotélica que constitui o discreto e, por isso, a observaçāo das suas convençōes permite demonstrar-se que, em sua modelização retórica, a identidade do tipo é definida como representaçāo, quero dizer, como um estilo de aplicar estilos, ou um estilo de afctar uma aparência. Por isso, a capacidade de escolher e aplicar um decoro e nāo outro define também a superioridade social do tipo, como uma forma da representaçāo adequada às situaçōes móveis da hierarquia. Logo, também, sua distinçāo, como cxcelência e poder, decorre da forma da representação. Nas letras luso-brasileiras sciscentistas, a forma da representação é sempre retórica e resulta de esquemas próprios de uma racionalidade não-psicológica.

O estudo dos dispositivos retóricos permite que se faça uma reclassificaçāo dos usos seiscentistas da agudeza e dos vários gêneros e estilos dos discursos, segundo ocasiōes da hierarquia especificadas como decoro ético-retórico. Permite também que se demonstre que a agudeza seiscentista, geralmente desqualificada como "afetação" e "mau gosto" nas histórias literárias, é bem outra coisa, pois permite rarefazer a generalidade anacrônica de categorias críticas herdadas do século XIX, e por isso se observa que aquilo que era talvcz evidente a ponto de nāo ter sido visto surge nas formas por vezes estranhas, pois históricas, de uma nova visibilidade do objeto cultural. A operação de Chartier ensina a crítica do etnocentrismo das lcituras, enfim, e só isso já ć uma lição magnífica, que caberia ao estudioso de literatura incluir e, depois, gencralizar.

Os estudos brasileiros sobre o que hoje se unifica como "Barroco" sāo geralmente realizados num lugar institucional, acadêmico, que pōe em cena, nas apropriações dos resíduos, um padrão de legibilidade que é específico do estudo da literatura densamente letrada da modernidade pós-vanguarda, modelada segundo as características do texto impresso. O mesmo padrão de legibilidade autoriza critérios de orientaçāo temporal, profissional e institucional do sentido das apropriaçōes, como os de racionalizaçāo negativa da forma, utopia política, ruptura estética, subjetividạde, originalidade radical, plágio, ambigüidade programática, mercado e direitos autorais. Quando é aplicado retrospectivamente a discursos originalmente ordenados segundo outras categorias de pensamento e convenções técnicas, veiculados por outros suportes e meios, visando outros fins e lidos, vistos ou ouvidos por outros públicos segundo outros sentidos dados à experiência do tempo, o padrão de legibilidade do impresso é evidentemente exterior. Generalizando retrospectivamente, universaliza um modo de apropriação, entre outros, como natural. Lembro aqui dois casos, ambos do século XVII luso-brasileiro, que considero exemplares desse modo anacrônico de ler: o da sátira e o da oratória. No caso da sátira, a mediaçāo do critério alfabetizado e literário do impresso faz com que hoje se entenda como defeito estético o que, no século XVII, era qualidade retórica do decoro. Então, o discurso aplicava outros dispositivos de modelização, orientando-se por outro sentido do tempo, circulando por outros meios, segundo outras apropriaçōes. Por exemplo, na Bahia do final do século XVII, o poema manuscrito do panfleto anônimo, da folha avulsa, do papel pregado na porta da igreja, era lido em voz alta para um público analfa- 
beto nas formas de recitaçāo, de declamaçāo e da dramatização, facilmente memorizáveis, dada a trama típica, fortemente estereotipada, dos poemas logo apropriados em novos circuitos quando copiados ou oralizados em novas situaçōes, ou seja, com novas deformaçōes. Na modelização retórica da sátira, ressalta imediatamente o ut pictura poesis horaciano, que é uma doutrina do decoro, isto é, uma doutrina dos efeitos de estilo adequados às recepções, que entāo regula toda a poesia e a prosa. A sátira aplica o ut pictura porque a oralizaçẫo e a audição são fatores constitutivos do sentido das suas formas. Segundo o preceito do ut pictura, a sátira é um gênero popular que adapta o tempo curto e movimentado da praça e das ruas ao estilo, como um pressuposto daquilo que representa. Tal tcmpo deve ser adaptado esquematicamente para o destinatário, ou seja, a sátira deve ser composta com as formas esquemáticas que a percepçāo assume na movimentação e no barulho de uma assembléia popular. Por isso mesmo, a sátira aplica técnicas estilísticas que compõem o discurso como objeto para ser visto ou ouvido a distância, de uma vez só, e com clareza absoluta: a caricatura, a mescla estilística, a carnavalização, a deformação e a obscenidade se cvidenciam, no caso, como adequadas à recepção das ruas. Sua aplicaçāo é um preceito técnico do gênero, que exige a representação esquemática, como se a representaçāo fosse pintada com uma broxa ou desenhada com um carvāo grosso, e não é decorrência necessária e imediata, como se costuma dizer no Brasil, da psicologia ressentida ou doentia do homem que a produz. Por isso, quando o mesmo discurso satírico é editado e lido hoje na forma do livro, que é a nossa, cometemos enganos de apreciação quando afirmamos que é mal escrito, ou estilisticamente inacabado e imperfeito. E cometemos tais enganos de apreciação porque a destinação inicial da sátira não pressupunha a escrita. Seu inacabamento e imperfeiçāo, ao contrário de serem uma carência estética, săo bem a evidência de um desempenho extremamente adequado do artifício poético destinado à rapidez da audição, como con. trafaçāo ou fingimento estilístico de uma inépcia que se torna apta para contemporâneos que conhecem a convenção. Para aqueles que năo a conhecem, apta ou inepta, segundo várias possibilidades de apropriaçāo.

Quanto à oratória, o pressuposto de uma estilistica que entende as metáforas do sermão como expressāo da psicologia do orador năo considera sua convençāo retórica anônima e colctivizada. Por exemplo, não considera a orientação prática de tais efeitos quando capturados no espaço-tempo da igreja jcsuítica contra-reformada, em que outras formas ordenam a percepção. Lembro que, na doutrina do scrmāo sacro, a actio retórica prevê a matéria do corpo do padre como um elemento do sentido. No descmpenho oral do sermão, o corpo se transforma dramaticamente em signo da racionalidade de Corte discutida por Elias e Chartier, especificando-sc como teologia-política e providencialismo. No caso da oratória jesuítica portuguesa do XVII, que é a de Vieira, a actio metaforiza os Exercícios Espirituais de Loyola, fazendo com que a prudência e o engenho se evidenciem em padrões convencionados dos gestos, das posições das mãos e dedos, da direção do olho, da intensidade da voz - por exemplo, a fala em falsete típica do fidalgo português, a fala bradada, a fala sutil. A actio prescreve um sentido geral para a apropriação de um público contemporâneo, que teoricamente partilha as mesmas convenções. Como evidencia Chartier, a apropriaçăo deve ser definida na infinidade múltipla e contraditória de suas deformaçōes. Lembro que, retoricamente, a técnica do sermão prevê duas recepçöes, segundo os dois modelos culturais do discreto e do vulgar. Para constituir o destinatário discreto, Vieira costuma citar o conceito predicável em latim e, ao mesmo tempo, traduz o latim adaptando a tradução às circunstânci- 
as e à inteligibilidade de um destinatário vulgar constituído no mesmo ato da traduçăo. Ou seja: o sermāo teatraliza dois destinatários típicos. Determinar os modos retóricos, teológico-políticos e éticos com que a enunciação se ocupa de cada um deles pode ser pertinente, por exemplo, para se determinar os padrōes de hierarquização operados na representação, como prática.
Neste sentido, a consideração dos dispositivos de invenção dos discursos seiscentistas e a das condições materiais de sua produçāo e consumo também deveriam, inicialmente, extrapolar a área especificamente "estética" ou "literária" das abordagens contemporâneas, na medida que são retóricos. Mas isso seria matéria para outro braconnage.

Endereço: Av. Prof. Luciano Gualberto 403, sala 4 - Cidade Universitária 05508 - 900 - São Paulo 